\title{
A CRITICAL DISCOURSE ANALYSIS OF USTADZ KHALID BASALAMAH'S LECTURE FRAGMENT ON YOUTUBE ABOUT "DURHAKA KEPADA ORANG TUA KARENA ISTRI"
}

\author{
Muftihaturrahmah Burhamzah \\ English Department, Universitas Negeri Makassar \\ Jl. Mallengkeri Raya, Parang Tambung, Makassar, Indonesia \\ Email: amaburhamzah@unm.ac.id \\ Nelly \\ Instansi Balai Diklat Keagamaan Makassar \\ Jl. Sultan Alauddin No. 105a, Makassar, Indonesia \\ Email: nellywahidin@gmail.com \\ Alamsyah \\ German Department, Universitas Negeri Makassar \\ Jl. Mallengkeri Raya, Parang Tambung, Makassar, Indonesia \\ Email:der_alamsyah@unm.ac.id
}

Article received August $4^{\text {th }}, 2021$; Article revised September 21 $1^{\text {th }}, 2021$; Article approved October $22^{\text {th }}, 2021$

\begin{abstract}
Religious lecture nowadays can be found not only by joining Tablighi Jema'ah in the mosque but also by searching the desired religious lecture theme on YouTube, delivered by the desired ustadz. Even though sometimes the content of the lectures found on YouTube are not in their full version. However, the messages can be received. The theme about wife as the cause of disobedience to parents still becomes a central and popular theme to be delivered by ustadz nowadays. This phenomenon can be related to the nature of a woman as a wife who mostly found difficulty adapting to their spouse's family because of her nature to be dominantly self-controlled by feelings. This study aims to critically analyze the discourse of Ustadz Khalid Basalamah Lecture fragment found on YouTube about wife as the cause of disobedience to parents. This study was conducted by analyzing three aspects of Fairclough's Critical Discourse Analysis Method, namely textual analysis (microstructural analysis), discursive practice analysis (mesostructure analysis), and socio-cultural analysis (macrostructural analysis). The study found that the discourse is: (1) using forbidding words repeatedly to show reinforcement of the messages, (2) distributing messages delivered by Ustadz Khalid Basalamah, who is believed in having 'power' to deliver a religious lecture to Muslims as the consumer by his way that is by persuading the audience to think logically, (3) Have important messages to be delivered in building a harmonious family and future society.
\end{abstract}

Keywords: ustadz khalid basalamah channel, lecture fragment, disobedience toward parents

\section{INTRODUCTION}

A very drastic development in the use of the internet has occurred in this era of globalization. This can be easily seen, namely by the number of people connected to the internet when using gadgets. People prefer to get information directly or in audiovisual form, including audiovisual information provided by YouTube. Various circles of society, both young and old, have used their gadgets to connect to the internet. This includes accessing YouTube, thereby increasing the intensity of gadgets and connections to the internet by the public. This has happened globally, including in our own country, Indonesia (Djunu, 2016).

YouTube itself is a product of the development of Information Technology in this era. Information technology can be interpreted as a tool to support work or tasks related to information (Haag \& Keen, 1996). Advances in Information Technology are in line with the development of science, and of course, its presence brings both positive and negative impacts. The impact received depends on the discretion of the user to use 
Information Technology applications. The community must have a strong faith and moral foundation to filter out the positive impacts and discard the negative impacts of Information Technology in this era of globalization (Suparno, 2017).

There are approximately 25 million internet users in Indonesia, according to the calculations of the Indonesian Internet Service Providers Association (APJII) (Basri, 2014). In Indonesia, it was even found that the number of mobile phone users has exceeded the total population of Indonesia. This indicates that almost everyone has two or three mobile phones in their life (Samosir et al., 2018). Likewise, with the internet accounts that are known to have been connected from each of these residents. Information obtained from the internet, including YouTube, has made it easier to carry out their daily activities. Activities that can be done with the internet include watching, looking for information, using social media for communication, etc. The most striking thing that has happened in this 'gadget' generation is where most people have switched from watching on television to watching videos on YouTube, both entertainment and educational and informational. As many as $52 \%$ of $30 \%$ of the population in Indonesia have switched to watching YouTube from previously watching TV (Buhang, 2015).

YouTube can be interpreted as a digital media site (video) that can be downloaded, uploaded, and shared throughout the country (Baskoro, 2009). Youtube has become very familiar among people to view the latest news, find information, watch movies, listen to songs, or watch video tutorials. The actual positive impact is that it is easy to get news or information and education through valuable videos. On the other hand, the negative impact obtained is the availability of harmful content from YouTube videos that are useless and can even damage morals if consumed uncontrollably (David, et al. 2017).

Some of the motives for using YouTube by the public include (1) the motive for seeking entertainment to relieve fatigue, (2) the motive for seeking information that can increase knowledge and facilitate their daily activities, (3) the motive for personal identity by finding videos that become their favorite each of the most related to their personality, (4) self-actualization motives by uploading videos which are a form of their self-actualization, (5) motives for seeking social empathy such as curiosity to see the condition of others who are afflicted by a disaster (Akbar, 2018).

YouTube, according to Sianipar (2013), has played a role primarily as a learning medium that contains elements of moving images (visual) and sound (audio). It is no exception as a medium of spiritual and spiritual learning with religious nuances, such as Islamic lectures, which previously could only be accessed by following the symbols of Islam through sermons in mosques or science councils. Now, Islamic lectures can be easily accessed via YouTube anytime and anywhere.

The lecture itself is one of the media that is quite popular with the Indonesian people to obtain information. We can generally listen to lectures in places of worship such as mosques, churches, or other public places. Lectures are included in a speech that is delivered persuasively to listeners to convey and explain or broadcast instructions related to religious teachings. Lectures need an oral skill or public speaking, which is generally delivered by someone who has expertise in the field or a particular discipline. The themes presented are general themes by the current situation in the community or the activities being held. A good lecture has a complete structure consisting of an introduction, content, and closing and is delivered in polite language, and is easily understood by the listeners. Lectures must be objective, transparent, proven accurate, and must not convey hoaxes or lies.

Lectures can be divided into special lectures and general lectures. Special lectures aim to provide advice or instructions to special masses or listeners, both in terms of material and other factors. At the same time, a public lecture is a lecture that contains a message that aims to provide information whose audience is the wider community or the general public. However, a lecture has a purpose that is grouped into three dimensions, namely: 1) informative, to provide information to get to know something or to understand the message to be conveyed to the listeners; 2) persuasive, to invite the audience to follow the advice or whatever has been conveyed in the lecture; 3 ) argumentative, to convey a particular topic by presenting an 
argument with understandable examples so that listeners can understand the topic presented; 4) recreational, to entertain or make the audience's heart happy, satisfied and happy; 5) Narrative, to tell one particular thing to the audience or listeners.

The types of Information in lecture texts can be categorized into five, namely: (1) Function-based information is Information that depends on the material and also the use of Information, including Information that increases knowledge such as lecture texts about curriculum changes, educational Information (which teaches readers) such as lecture texts about effective learning techniques, Information that pleases readers who are fictional (imaginary or entertainment), such as lecture texts about short stories, comics, and caricatures; (2) Information based on the format of presentation is Information based on the form of presentation of the Information, such as in the form of writing (news, articles, feature essays, reviews, columns, and works of fiction), photos, cartoons or caricatures; (3) Information based on the location of the event is Information based on the place where the incident took place which is divided into regional Information, national Information, and foreign Information; (4) Information based on fields of life is Information based on existing fields of life, such as education, sports, music, literature, culture and science and technology; (5) Information based on areas of interest in the lecture text is divided into 4, namely Information concerning the safety or survival of readers, Information concerning changes and effects on the lives of readers, Information about new and practical ways or tips for readers to improve their quality of life, and Information about opportunities for readers to get something (Putri, 2020).

One of the topics of religious lectures commonly delivered is household matters, especially problems or conflicts that often occur in them. This topic is common for Muslims because the audience consists of Muslims and Muslim women, both married and those who are about to get married. Married audiences can also be newly married couples or those who have been married for a long time. The most common problems are problems or conflicts between a daughter-inlaw and her mother-in-law as a participant of this topic. Including a confused husband in the middle is also the right audience for Islamic lectures on this topic. Thus, Islamic lectures on this topic become very interesting to analyze.

In this study, critical discourse analysis will be conducted on Islamic lectures with "Wife Causes Disobedience to Parents" presented by Ustadz Khalid Basalamah on Youtube. The critical discourse analysis method used is the Fairclough method. Critical discourse analysis is one method that can be used to analyze discourse (oral or written) where the object of analysis is 'language' and the accompanying context. Fairclough's critical discourse analysis views language as a powerful practice and links the micro text with the macro community context. According to Fairclough, there are three stages of critical discourse analysis, namely textual analysis (microstructural analysis), discursive practice analysis (mesostructure analysis), and socio-cultural practice analysis (macrostructural analysis) (Sumarti, 2010). Thus, this research will be analyzed on this Islamic lecture, including such three dimensions of analysis.

\section{RESEARCH METHOD}

This study uses a qualitative approach with the method of critical discourse analysis, according to Fairclough. The qualitative approach leads to findings not obtained through static procedures or other forms of relationships and emphasizes the interpretive and objective meaning of truth (Rahmat, 2009). The type of research is explanative, which means that this research will analyze the relationships between variables in depth through language (Sugiyono, 2013) in Ustadz Khalid Basalamah's lecture entitled "Wife Causes Disobedience to Parents."

The data from this research is in the form of discourse analysis of Ustadz Khalid Basalamah's lecture entitled "Wife Causes Disobedience to Parents," which is transformed into text sourced from Youtube videos on the "Anwar Family" channel. According to Norman Fairclough, the analysis will be carried out at the microstructural, mesostructure, and macrostructural levels of the text by the Critical Discourse Analysis. The microstructural analysis includes an analysis of the language used in the text, while microstructural analysis includes how the 
discourse is produced, distributed, and consumed by the audience. Meanwhile, the macrostructural analysis includes the linkage of the text with socio-cultural practices that occur in society.

\section{DISCUSSION}

According to Setiawan (2007), the factors that can cause damage to the relationship between parents-in-law and daughter-in-law are:

\section{Culture}

Cultural factors explain the misunderstanding of the responsibilities of parents and children. Some parents think that they still have to be responsible for their children even though their children are married in certain cultures. Their parents are worried about their children's independence after marriage, so they have to intervene. While on the other hand, children and in-laws want to live independently, and they want to try to feel how to take care of their household.

\section{Child's independence after marriage}

Contrary to the previous statement, this factor assumes that most couples are married but still live at their parents' house. Because they are not financially independent, it is only natural that parents still interfere in their children's household affairs with this intervention. For example, when their child is entrusted to their grandmother, while their parents both work. Intensive communication between the grandmother and the granddaughter will cause the grandmother to be protective of her granddaughter so that there will be a desire always to want to protect her grandson when parents want to apply discipline to their grandchildren. So it can end up with a misunderstanding.

\section{Ownership}

A lack of understanding of religion causes ownership. In Islam, when a daughter marries, she belongs to her husband, while if a son marries, he remains his mother's property. If this is not understood correctly, then parents who feel that they have given birth and raised them will feel that they have rights over their children forever. Meanwhile, the son-in-law feels he has rights over his partner because of his marital status. Each party feels jealousy of each other because they consider each other to steal affection from loved ones.
Based on the third factor, namely, the 'ownership' factor mentioned above, many Ustadz raise the topic in their lectures. Because all misunderstandings must be corrected, Islam is awarded a life guide in the form of the Qur'an and the Hadith of the Prophet so that when he encounters problems in life, then a Muslim should return to what is written in the Holy Book of Islam. In total, the data from the conversion of lectures into text form from Ustadz Khalid Basalamah on the Youtube channel 'Anwar Family' with the video title "Wife as the cause of disobedience to parents" will be presented as follows::

\begin{abstract}
"Banyak orang ribut sama mertuanya, ribut sama iparnya karena dia tidak siap. Dia Cuma mau pasangan hidupnya saja, eksklusif. Iparnya datang, gak dibukain pintu. Suaminya mau bakti sama ibunya, cemberut. Dosa dia, gimana caranya... hukum syar'i tidak bisa diubah. Ini bukan hukum rimba, hukum Allah, pencipta langit dan bumi. Lakilaki wajib bakti kepada orang tuanya sampai dia mati, dianya yang mati. Kalau orang tuanya mati atau hidup tetap wajib dia bakti ndak boleh istri jadi penghalang suaminya untuk ketemu ibunya, bakti ngantarin makanan, siarahin kuburnya kalau mati. Gak boleh, haram. Dia harus dukung. Banyak istri bangkang dalam hukum ini sampai seorang anak berani bangkan pada orang tuanya. Bahkan saya tau ada kejadian di Jakarta karena istrinya gak suka tadinya dia belikan ibunya rumah di sebelah rumahnya, dipindahin ibunya.
\end{abstract}

Durhaka sama orang tua. Sampai ulama mengatakan kalau ada seorang anak laki-laki menikah kemudian dia biarkan ibunya duduk di belakang sementara istrinya duduk di depan dia durhaka itu. Ah itu namanya durhaka. Kecuali ibunya yang minta. Tidak boleh, ini wanita harus paham nih, gak bisa. Kalau wanita seperti ini diceraikan, halal dalam agama Islam. Dia menjadi penyebab si anak putus dengan orang tuanya. Halal diceraikan. Gak boleh... lain kalo perempuan yang memang menikah, suaminya nomor satu. Sama, Anda juga sebagai laki-laki tau perempuan ini pada saat menikah dia punya orang tua, dia punya saudara, kita punya ipar harus bisa datang ke rumah bertemu.

"Ustadz, mertua saya cerewet” gak papa, cobaan. Enaknya hidup gak mau ada cobaan, gimana caranya... harus ada cobaannya. Ada orang dicoba di pasangan hidupnya, di mertuanya, di iparnya, di anaknya, di tetangganya, banyak... harus ada cobaan, kalau gak ada cobaan, hidup kita datar terus gak ada seninya, kehidupan ini gak ada seninya. Dan manusia nanti tidak akan keluar potensi seseorang akan keluar kalau cobaan ada. Kita akan muncul ideide untuk mencari jalan keluar pada saat kapan? Cobaan ada... bayangkan kalau hidup kita datar terus, gak ada cobaannya, gak bakal keluar potensi kita. allah datangkan cobaan untuk kita itu untuk mengorek, mengeluarkan potensi yang ada. 
Hadapin, pecahkan. Pahala sabar didapatkan kapan? Pada saat cobaan datang... kalau cobaan tidak ada? Gimana bisa, gak mungkin... istri kita hidup 20 tahun di rumah tangganya sama orang tuanya dengan pola tertentu, cara makan, cara tidur, cara berpakaian. Kita pun hidup 30 tahun di ayah dan orang tua kita dengan cara makan dan cara hidup disitu lalu disatukan tiba-tiba mau bisa baik semuanya? Gak bisa, pasti ada penyesuaian. Asas yang penting dalam rumah tangga adalah yang benar memaafkan, yang salah meminta maaf, selesai. Dan jangan nginapkan masalah. Banyak orang laki-laki lemah, begitu istrinya marah gara-gara dia pergi ke ibunya langsung dia "ya sudah, saya gak usah ke ibu deh kalau begitu dari pada saya ribut sama istri saya", Subhanallah! Dudukkan istri Anda, "Kamu tahu gak hukum agama? Saya wajib bakti dengan ibu saya, durhaka saya kalau gak kesana, kamu pun berdosa kalau kamu lakukan ini”, nah harus begitu. Kalau perlu sang istri sokong "kamu ke ibumu, ayo, saya temenin, kapan ke ibu, kapan ke ayah", berikan sokongan."

\section{Textual Analysis (Microstructural)}

Textual analysis is one of the dimensions that will be analyzed in discourse events according to Fairclough's stated, namely through linguistic analysis and by looking at vocabulary, semantics, and sentence structure. The coherence and cohesiveness needed in shaping the understanding of discourse are also aspects that can be analyzed in discourse, according to Fairclough (1). Ustadz Khalid Basalamah's lecture on YouTube with the theme "wife as the cause of disobedience to parents" can be analyzed textually by paying attention to the elements or aspects that Fairclough has stated.

From the analysis results, it was found that one striking pattern of the grammar used was the repetition of forbidden sentences. According to Ningrum et al. (2018), the repetition of sentences in a discourse shows an affirmation or reinforcement of the message to be conveyed by the speaker, in this case, Ustadz Khalid Basalamah. Here are some fragments of discourse that show the pattern of repetition of prohibited phrases or sentences with the same meaning:

.... ndak boleh istri jadi penghalang suaminya untuk ketemu ibunya, bakti ngantarin makanan, siarahin kuburnya kalau mati. Gak boleh, haram.

... dia biarkan ibunya duduk di belakang sementara istrinya duduk di depan dia durhaka itu. Ah itu namanya durhaka. Kecuali ibunya yang minta. Tidak boleh, ini wanita harus paham nih, gak bisa. Kalau wanita seperti ini diceraikan, halal dalam agama Islam. Dia menjadi penyebab si anak putus dengan orang tuanya. Halal diceraikan. Gak boleh... lain kalo perempuan ...
There is also a phrase that is often mentioned in the discourse of the lecture, namely the phrase "gimana caranya". This phrase can firmly break the opinion of the case examples presented in the sentence before the phrase is spoken. The use of this sentence gives the audience the impression that the case example presented in the sentence before the phrase does not make sense according to the cognition of the speaker, in this case, is Ustadz Khalid Basalamah. Here are some fragments of sentences that end with the phrase 'gimana caranya':

\section{Suaminya mau bakti sama ibunya, cemberut. Dosa dia, gimana caranya... \\ Enaknya hidup gak mau ada cobaan, gimana caranya..}

The interrogative sentence is used to recall the audience so that they are more aware of the statement conveyed by the speaker after the interrogative sentence is spoken. That is one of the language styles used by Ustadz Khalid Basalamah. Although the lecture technique is a one-way lecture, the speaker tries to throw questions to recall the audience's awareness to stay focused on the content of the lecture. Here are two examples of sentence fragments that use the interrogative sentence:

Kita akan muncul ide-ide untuk mencari jalan keluar pada saat kapan? Cobaan ada...

Pahala sabar didapatkan kapan? Pada saat cobaan datang... kalau cobaan tidak ada? Gimana bisa, gak mungkin...

Kita pun hidup 30 tahun di ayah dan orang tua kita dengan cara makan dan cara hidup disitu lalu disatukan tiba-tiba mau bisa baik semuanya? Gak bisa, pasti ada penyesuaian.

In addition, in the discourse, there is also a form of conversation using third-person pronouns. The speaker uses the conversational form to explain examples or examples in explaining what the speaker explains before or after the conversation is spoken. According to Barnard (2018), in explaining something, giving an example or example is very helpful for listeners to understand the content or message that the speaker wants to convey. Some examples of sentences that show examples of these conversations are:

\footnotetext{
"Ustadz, mertua saya cerewet"

"Ya sudah, saya gak usah ke ibu deh kalau begitu dari pada saya ribut sama istri saya"
} 
"Kamu tahu gak hukum agama? Saya wajib bakti dengan ibu saya, durhaka saya kalau gak kesana, kamu pun berdosa kalau kamu lakukan ini"

"Kamu ke ibumu, ayo, saya temenin, kapan ke ibu, kapan ke ayah"

\section{Mesostructural Analysis}

In this analysis, the process of production, distribution, and consumption of discourse becomes the target of analysis, according to Fairclough. Judging from the production process, in this case, the speaker, namely Ustadz Khalid Basalamah, it is necessary to know his cognitive background and his power in distributing his lecture messages. After that, the distribution process is chosen to convey the message in what form. The one-way lecture method is the method used in this discourse distribution process. The style or distribution pattern has a distinctive form, namely, using a persuasive style with an invitation to consumers to think logically regarding the message conveyed. This method is typical, aiming to make it easier for consumers to receive the message's contents because it follows their logic of thinking. The consumers of this discourse are Muslims and Muslim women who have or will be married.

Ustadz Khalid Balamah was born on May 1, 1975, in Makassar with the full name Ustaz Dr. Khalid Zeed Abdullah Basalamah, Lc., M.A. He has graduated from college by obtaining a bachelor's degree at the Islamic University of Medina, Saudi Arabia; a master's degree at the Indonesian Muslim University; and a doctorate at Tun Abdul Razak University in Malaysia. Currently, Ustaz Khalid Basalamah is active as a preacher in his homeland, Indonesia. In addition, there are other activities, such as culinary business and business, that also function as a medium for Islamic symbols, ta'aruf, and alms. In addition, he also pursues institutional activities as General Chair of the East Jakarta Ats-Tsabat Foundation, Chair of the Irian Da'i Delivery Forum, and Advisor to Wesal TV Jakarta (Elmira, 2019).

Based on the description of Ustadz Khalid Balamah's cognitive background above, it is known that speakers have considerable power to be heard by consumers of this discourse. Norman Fairclough says that there is a close relationship between critical discourse analysis and the element of 'power.'
A text is judged because of the power behind the production of the discourse that makes consumers of the discourse interested in consuming the discourse (Sumarti, 2010).

The distribution of this discourse uses a one-way lecture method. The success of discourse content to be consumed appropriately by consumers depends on selecting the proper distribution process. Persuasive style and an invitation to the audience to think logically is the right way to attract sympathy and awareness of the audience as applied in this discourse. According to Matz et al. (2017), speech patterns that invite the interlocutor to think logically provide specific psychological effects that make the audience more interested or sympathetic to the speaker's content.

The consumers of this discourse are Muslims and Muslim women who have or will be married. Because the content of the discourse delivered by the speaker is an Islamic lect ure, the target consumer is right. A Muslim always tries to find out the problem based on the Qur'an and the Hadith of the Prophet. In this discourse, the topics discussed are problems that are very common in the social world. Muslims can gain enlightenment from the lecture's content because the speaker discusses the topic from the Muslim point of view and the point of view of Muslim women, both unmarried and married. Even for those who have just married or have been married for a long time.

\section{Macrostructural Analysis}

The macrostructural analysis focuses on the relationship of the text with the context that accompanies it, which in this case is the socio-cultural aspect of society. In an Islamic lecture with the title "Wife Causes Disobedience to Parents" brought by Ustadz Khalid Basalamah on Youtube, it can be seen that the conflicts that often occur between daughters-in-law and mother-in-law in society are the background behind the discourse. Moreover, in Islam, the problem or conflict has been explained in the Qur'an regarding the problem. The speaker, in this case, Ustadz Khalid Basalamah, as someone who has the 'power' to voice the explanation, then chooses the topic to 'distribute' his message to consumers, namely Muslims, in his way of delivery. 
Many factors can cause conflict between daughter-in-law and mother-in-law, including housework factors, economic factors, differences in mindset, different parenting styles, misunderstanding and communication factors, differences in interests accompanied by domination or coercion by others from mother-in-law to daughter-in-law. Conflicts that occur between daughter-in-law and mother-in-law will ultimately have an impact on creating an uncomfortable home atmosphere. This issue does sound strange, but such conflicts are indeed interesting to discuss. Because the tension and competition between the two is indeed a real thing, it is clear why, and not just something too exaggerated.

It is not uncommon for a daughter-inlaw to often quarrel or be upset with her mother-in-law. This does not only happen in Indonesia but also often happens in other countries. This is based on the uniqueness of women who are dominated by their feelings, including making decisions. Thus, everything that he experiences, he will experience with his feelings, including what he sees or hears. This is also the reason why we rarely find conflicts between father-in-law or son-in-law. In-laws are often portrayed negatively by society. Javanese people often make an analogy with the term "tongue-in-law" because of the image of the mother-in-law, who is considered a very talkative person (Suciati and Sofyan, 2020). So that the assumption is that being independent in the household is much better.

There are differences in marital satisfaction between married couples who are independent and married couples who live with their parents/in-laws. The causes of the conflict include differences in values and attitudes with the mother-in-law who demands too much and interferes in children's household matters or because marriage is not yet mature as part of a new household. Meanwhile, the leading cause that most often causes debates and even quarrels between the two is due to miscommunication. One of the parties harbored a disagreement so that when everything was unstoppable, the way of venting it out exploded. Plus, the tendency of women to bring up old problems, which ultimately makes the miscommunication problem much more complicated (Suciati and Sofyan, 2020)
On the other hand, Mustikarani (2012) explains that it is inherent in every mother that her married son remains her responsibility so that without realizing it, she has interfered in her own child's household life. Cause of quarrels usually comes from the mother-inlaw, who expects her daughter-in-law to treat and pamper her child as well as possible. Mother-in-law is sometimes too quick to label her daughter-in-law's ability to take care of the household and ignores that almost every newly married woman needs adaptation. Thus, the daughter-in-law becomes uncomfortable with every demand from her mother-in-law (Suciati and Sofyan, 2020).

Most daughters-in-law who live with their in-laws do not feel well in their lives. At the same time, welfare itself must be strived to be achieved through self-accustoming or by learning a lot. So, welfare does not appear automatically in each individual. It is only the individual problem that is still unable to control emotions properly, which is triggered by feelings of discomfort, affecting his assumptions regarding welfare (Rahmah, 2019). In the daughter-in-law's eyes, the mother-in-law often makes her sad and uncomfortable by being dominant because she knows everything about her son or is too worried, which is against her will who wants to live her household independently, wants to learn and enjoy how it feels - married without interference from anyone, including their parents. Thus, the opinion arises that navigating the household ark is not as beautiful as imagined. The daughter-in-law also feels a lot of pressure (Rustiyaningsih, 2018).

In the end, mutual positive thinking between the two parties becomes a middle ground that every human being has a good side and a right side in addition to his weaknesses and ugliness. The terms 'in-law' and 'daughterin-law' are just labels because, basically, their relationship as mother and child. Because after all, the daughter-in-law must be aware that in-laws have a very high contribution to the presence of the household. The contributions in question include approval of marriage, being part of two families who meet and be friends with each other, contributing to uniting two prominent families, and establishing a friendly relationship between parents and grandchildren (Suciati and Sofyan, 2020). 
The quarrels between the mother-inlaw and the daughter-in-law are becoming more complicated for the husband, whether it is a fight that openly or avoids each other or is silent and harbors annoyance. This husband's confusion is due to the difficulty of determining who will defend himself, even though sometimes the husband thinks that his mother exaggerates trivial things. He felt confused to keep defending his wife because the husband could not be disobedient to his mother. The fact that happens is that the husband tends to ask his wife to be patient or do what her mother wants in the end. The problem is getting worse because the wife will judge that the decision is not fair to her. However, regardless of the wife's view of her in-laws, Islam does not justify if the wife is the cause of her husband's disobedience to his parents (Suciati and Sofyan, 2020).

Problems regarding daughter-in-law and mother-in-law can occur more or less due to the explanation above. The function of this discourse is to solve problems based on the laws outlined in the Qur'an and to realign the understanding of Muslims. The impact of the message in this discourse is comprehensive because it can make family relations more harmonious and broadly can make society in the future more harmonious. After all, every family is a component of society.

\section{CLOSING}

Based on the results of the discourse analysis in the form of an Islamic lecture on YouTube hosted by Ustadz Khalid Basalamah with the title "Wife as the Cause of Disobedience to Parents," it can be concluded as follows, namely: (1) This discourse uses forbidden words repeatedly to show reinforcement towards the message conveyed, (2) This discourse distributes the message brought by Ustadz Khalid Basalamah, who is believed to have the 'power' to deliver religious lectures to Muslims as consumers in a way that invites listeners to think logically, (3) This discourse has an important message in building a harmonious family and building a harmonious future society.

\section{ACKNOWLEDGEMENT}

The author would like to thank for any participants in this research for their cooperation.

\section{REFERENCES}

Suciati dan Sofyan N. 2020. Mewujudkan Keluarga Harmonis Melalui Pengelolaan Konflik Mertua dan Menant u. Prosiding Semnas PPM 2020: Inovasi Teknologi dalam Pemberdayaan Masyarakat Pasca Covid-19.

Samosir FT, Pitasari DN, Purwaka, dan Tjahjono PE. The effectiveness of youtube as a student learning Media (Study at the Faculty of Social and Political Sciences, University of Bengkulu). Record and Library Journal, Volume 4, No. 2, 2018.

Sumarti E. 2010. Analisis Wacana Kritis: Metode Analisis. Lingua Scientia, Volume 2, Nomor 2, November 2010.

Barnard D. 2018. How to structure your presentation with examples. Available on https://virtualspeech.com/blog/howto-structure-your-presentation.

Accessed on 26 June 2021.

Elmira P. 2019. Mengenal Ustadz Khalid Basalamah, Penceramah yang Punya Bisinis Kuliner Khas Timur Tengah. Available on https://m.liput an6.com/lifestyle/read/3 963360/mengenal-ustadz-khalidbasalamah-penceramah-yang-punyabisnis-kuliner-khas-timur-tengah. Accessed on 26 June 2021.

Matz S, Kosinski M, Nave G, and Well DS. 2017. Psychological Targeting as an Effective Approach to Digital Mass Persuasion. Proceedings at the National Academy of Science 114 (48).

Rahmat PS. 2009. Penelitian kualitatif. Equilibrium Vol 5 No.9 January-Juny 2009: 1-8.

Putri AS. 2020. Jenis-Jenis Informasi dalam Teks Ceramah. Available on https://www.google.com/amp/s/amp.ko mpas.com/skola/read/2020/09/15/2000 15569/jenis-jenis-informasi-dalamteks-ceramah. Accessed on 26 June 2021.

David ER, Sondakh M, and Herilama S. 2017. Pengaruh konten vlog dalam youtube terhadap pembentukan sikap mahasiswa ilmu komunikasi fakultas ilmu sosial dan politik universitas sam ratulangi. Acta Diurna VI/1/2017. 
Buhang FK. 2015. TV ditinggalkan ini tontonan favorit baru orang indonesia. available on https://www.google.com/amp/s/amp.ko mpas.com/tekno/read/2015/11/25/1231 0007/TV.ditinggalkan.ini.tontonan.fav orit.baru.orang.indonesia.

Basri ASH. 2014. Kecenderungan Internet Addiction Disorder Mahasiswa Fakultas Dakwah dan Komputer ditinjau dari religiositas. Jurnal Dakwah , Volume XV, No.2, Tahun 2014.

Suparno P. 2017. Membangun sikap diskretif dalam menyikapi perkembangan teknologi dalam penghayatan hidup bakti. Pertemuan Piko CB Rayon DIYJateng-Bali, Syantikara 18 November 2017.

Djunu A. 2016. Pemanfaatan Fitur Internet pada Smartphone oleh Masyarakat. ejournal "acta diurna" Volume V No.5 Tahun 2016.

Ningrum SA, Sunarti L. 2018. Penggunaan Bahasa pada Poster di Kota Bandar Lampung serta implikasinya. Jurnal kata (Bahasa, Sastra, dan Pembelajarannya) Februari 2018.

Sugiyono. 2013. Metode Penelitian Pendidikan Pendekatan Kuantitatif, Kualitatif, dan R\&D, Bandung: Alfabera. halaman 6.

Rustiyaningsih, Tia, (2018), Konflik Mertua sebagai Hambatan Generasi Komunikasi Lintas Budaya, Jurnal ilmu Komunikasi Andalan no 1 volume 1 (2018)

Rahmah, Milda, dkk, (2019).Konflik Sosial Menantu Yang Tinggal Serumah Dengan Mertua (Studi Kasus Di Desa Lempang Kecamatan Tanete Riaja Kabupaten Barru), Equilibrium jurnal pendidikan, Vol 7, No 2 (2019)
Mustikarani, Wahyu (2015). Hubungan Mertua dan Menantu yang Tinggal dalam Satu Rumah, diakses dari repository.unej.ac.id pada 4 Juni 2021.

Nuha, T. U. (2008). Potret Salafi Sejati (M. A. Q. E. A. Ahmad (ed.)).

Nurpratiwi, S. (2019). Urgensi Literasi Agama dalam Era Media Sosial. Proceeding Annual Conference on Islamic Education, 1(1), 94-99.

Nurzakiyah, C. (2018). Literasi Agama Sebagai Alternatif Pendidikan Moral. Jurnal Penelitian Agama, 19(2), 20-29. https://doi.org/10.24090/jpa.v19i2.201 8.pp20-29

Nusuki, N., Rifli, M., \& Ihsan, M. (2020). Literasi Agama Dalam Membentuk Sikap Mental Pada Masa Pandemi Covid 19. JKP (Jurnal Konseling Pendidikan), 4(2), 59-62.

Amanat Meneteri Agama pada Upacara Peringatan HAB Kemenag ke-75, (2021).

Saprillah. (2020). Kontestasi Antar Kelompok Keagamaan Dalam Masyarakat Islam: Dialektika, Subordinasi, Dan Strategi Mempertahankan Kelompok (1 ed.). Arti Bumi Intaran \& Zada Haniva (Citra Insan Prima).

Walzer, M. (1997). On Toleration. Yale University Press.

Yetri, Y., Iqbal, A. M., \& Amaliah, E. (2019). Literasi Keberagamaan Masyarakat Daerah 3T Di Kabupaten Pesisir Barat Serta Relevansinya Dengan Sikap Toleransi Terhadap Penganut Agama Minoritas. Al-Adyan: Jurnal Studi Lintas Agama, 14(2), 197-210. 
